\title{
The Dobrivliany Affair of 1886: A Nodal Approach to Consciousness Formation
}

\author{
A NDRIY ZAYARNYUK
}

Where love rules, there is no envy, no harm to the body, to health, honor, freedom or property, there is nothing evil.[1]

Not many studies have tried to penetrate the Galician countryside in the nineteenth century, and even fewer case-studies describe in some detail concrete events in concrete villages. Therefore, although the acquisition of national consciousness by Ukrainian peasants in Galicia has been a recurring theme in historical and political narratives, there are hardly any descriptions of how this acquisition took place in concrete places and with concrete people. One of the rare exceptions is a "conspiracy" in the village of Dobrivliany. Significantly, this case originally appeared in history as a socialist conspiracy, although later on it became clear that it involved national ideology as well.[2] The publicity this case obtained was due to the fact that a number of famous educated people were involved and to its connection with, perhaps, the only island of socialist agitation in Galicia outside of the province's two largest cities (L'viv and Krakow) - Drohobych and its oil basin.

The main problem with the Dobrivliany case, as with other similar stories about the acquisition of consciousness (either national or social), has been their teleological and heroic character, which corresponds neatly to the larger narratives of which these stories constituted an organic part. This teleology was based on the assumption that the peasantry necessarily had to obtain a certain national identity and/or class-consciousness. At first it was believed that the peasants, being Ukrainian by virtue of their ethnic "traits," simply had to realize this 
belonging and become conscious members of the nation: "the thing in itself" would become "the thing for itself." [3]

A more sophisticated approach stated that the moving force of this process was not the peasants' ethnic affiliation but certain shared experiences, which determined the outcome. In the case of Galician Ukrainians, such a profound experience was allegedly the social conflict between Ukrainian peasants and Polish landlords, which reinforced ethnic distinction and fostered the creation of a separate nation.[4] According to such an interpretation, the aspirations of the peasants and the intellectuals reached some concord, which was reflected in peasant correspondences to the popular press and materialized in joint political actions. Certain mechanisms, most importantly - reading clubs established by national organizations, served the cause of peasant enlightenment and constituted the link between peasants and the national movement.

Currently in Ukrainian historiography one can find a new revisionist trend, according to which social structures are no longer seen as determining the construction of the nation. A nation is seen as never actually "made," not so much a "construction" but rather a constellation appearing almost accidentally because of multiple factors interacting.[5] According to this explanation, political combinations play a much greater role than the barely mentioned social conflicts.

At the same time, these revisionist approaches represent a retreat from attempts to look into the practices of identity-construction. Giving up social structures and conflict as explicators to be used in their narratives, they retreat from social practice altogether; concentrating on ideas and plans they forget that, to paraphrase Arjun Appadurai,[6] imagination is a social practice, especially nationalist imaginings. I believe that detaching intellectual and cultural projects from the locations in which they were realized, as many historians do, has serious drawbacks for the way the nineteenth-century history of Galicia has been written.

One of the ways to remedy such a situation is to mobilize networks as both a research tool and a critical concept. Investigating networks in this particular case will help us "to turn from commonality to connectedness, from categories to networks, from shared attributed to social relations." [7] Doing so, I shall also try to remedy one of the shortcomings noticed in sociological applications of network theory - namely the neglect of and inability to deal with culture and agency.[8] For this I'll 
pay attention not only to the connectedness of people but also of meanings and their implications for the actions under consideration. We shall look at the network groupings linking peasants and intellectuals, try to map personal connections through which these networks operated, analyze texts read and produced in connection with these networks and detect the main sinews of the field of power relations of which both people and texts were part. Since the Dobrivliany networks were multiple, multilevel, with different densities and social distances involved between networks as well as within one of them, a detailed mapping of them would have overextended the present narrative. Therefore I'll limit myself to a very schematic description of the situation using some of the vocabulary developed by network theory. For the sake of brevity I have decided to eschew most of the references. All those interested in details of this affair and my sources can find themin a relevant chapter of my dissertation.[9]

\section{P A R T I}

Well known limitations imposed on historians by the nature of their discipline do not allow for the discovery of networks at work or the observation of their mechanisms. Historians can only search for the representations of networks at work and try to trace and reconstruct them. Quite often the only way to do this is to use the registers of alleged networks comprised by someone else. With the rise of the modern state and the development of new techniques to govern populations, various police and judicial bodies were involved in compiling lists of and rounding up networks potentially dangerous for the state. Let's start with a snapshot made by one such investigation.

In 1886 five peasants from the villages of Volia Iakubova and Dobrivliany were arrested, detained in Sambir and, after three-months' investigation, put on trial. All the charges against the defendants can be grouped around two major issues: socialist agitation and anti-clerical propaganda. It was the second trial against Galician peasants in which they were accused of socialist agitation. In the first one, which had taken place in Eastern Galicia several years earlier, all the agitation could be traced back to a single source: the leading Ruthenian radical Mykhailo Pavlyk and his sister. This previous affair had taken place not in a village but in a village-like town. 
The situation in Dobrivliany and Volia Iakubova was different. First of all, the case involved two villages and not one. Second, by 1886 the defendants had been active in local politics for several years. Third, two of them were regular correspondents for a popular Ukrainian newspaper. Fourth, there seem to have been connections with other peasants stretching over large distances, in one case - more than $60 \mathrm{~km}$. Fifth, there were connections and exchanges between peasants and intellectuals, Ukrainian as well as Polish. From this brief introduction we can see that at the very least the following networks were involved: intra-community networks of those prosecuted, an area network linking peasant activists of both villages, a pan-regional network of peasant activists often mediated and channeled into a nation-wide discursive field by the popular media, a network of democratic Ukrainian and Polish intellectuals, a network of Ukrainian nationalist intellectuals and, finally, the egocentric network of peasant activists grouped around the charismatic intellectual, Ivan Franko. Let's try to describe schematically the relations and "structural holes" of these networks, taking as our anchoring point a certain Hryhorii Rymar, a "node" that anchors some of the mentioned networks, appears on the margins of others, and serves as an outside reference in yet others.

Since much of our description rests on the prosecution's records, let's briefly go back to the trial. As already mentioned, the affair centered on two villages. The accusations against the peasants were based on the testimony of the parish priest from Dobrivliany. Also testifying were other peasants, woodcarvers decorating the local church, a teacher and a priest. Besides this testimony, there was "material" evidence found by the investigators during searches. This included a note titled "Le Comte," found in Rymar's possession and translated from a "German book."[10] There was also a poem "Confession" that Rymar had written down, which was found in the possession of the peasant Stupak from Dobrivliany. The poem ridiculed the sacrament of confession. There was also a pamphlet titled Jarek Bruzda, which Hryhorii Berehuliak, one of the defendants, claimed to have gotten from "an unknown student," and which he later destroyed. The defendant said that he "was not lending this writing to peasants to read, being afraid that their blood could be roused [from reading it]."[11] The rest of the texts found in the defendants' possession were perfectly legal. 
The defendants on trial were Hryhorii Rymar, Hryhorii Berehuliak, Ivan Stupak (all three from Dobrivliany), and Atanasii Mel'nyk and Tymko Prus'kyi from Volia Iakubova. It is worth noting that the court dropped all the accusations of socialist agitation against Rymar, and the only one found guilty of agitating against certain social classes and property was Berehuliak, the son of the village strongman, who had burnt a Polish socialist pamphlet and been afraid to show it to the other peasants. Was there any socialist agitation at all? Images of a wellorganized underground group can be found in the memoirs of Berehuliak's nephew, who back in the 1880s was of elementary school age. His stories fit very well with the heroic history of the Radical movement, which the party was writing in the 1920s. According to his story, the Dobrivliany group was very well organized, almost a party cell, held clandestine meetings and printed propaganda leaflets (25 copies each) allegedly written by Franko (although the texts in Berehuliak's description do not look like Franko's, and not a single copy has been preserved). He claims that the group's meetings were attended by people like N. Novakivs'kyi from the village of Torky in the Przemyśl district (around $60 \mathrm{~km}$ away), Ivan Mykhas from Morozovychi in the Sambir district (around $35 \mathrm{~km}$ away) and Fed' Derhalo from the village of Zavaliv in the Stryi district (around $26 \mathrm{~km}$ away).

On the one hand, all those listed by Berehuliak's nephew in the $1890 \mathrm{~s}$ became peasant members of the Radical Party, founded in 1890; on the other, all these names can be connected through one figure: the famous Ukrainian writer Ivan Franko, who, at a certain stage of his life, was a socialist. We know that he knew all the peasants mentioned by Berehuliak's nephew personally, and that from 1881 to 1883 he lived nearby in his native village of Nahuievychi. Nonetheless, immediately after the trial Franko mentioned in a private letter that he knew only two of five defendants in the Sambir trial, which means that he was not engaged in the workings of the in-village networks which centered around the peasant activists. When the reading clubs through which the defendants entered local politics were founded in Dobrivliany and Volia Iakubova in 1881, Franko did not figure among those who visited these clubs and gave lectures there. Even in the case of members of the extended network of peasant activists like Novakovs'kyi and Mykhas, we know that contact with Ivan Franko was initiated by them and not him. It is hard to imagine that already in the 1880s when Franko was just getting 
acquainted with the majority of them he was able to form such an extensive network.

Even before the appearance of Galician socialism and radicalism, there had been some opportunities for local peasant activists to cross the boundaries of their native communities. Moreover, for the creation of intra-village networks of like-minded peasant reformers the first impetus came not from urban intellectuals but from populist priests. Let's look at the example of Hryhorii Rymar, who could be seen as the leader of the whole "conspiracy." In his memoirs Hryhorii Rymar writes:

Rev. A. Chapel's'kyi, who baptized me in Dobrivliany in 1852, was from the time of my childhood until his death in January 1885 my greatest benefactor in the world. He always loved me as if I were his own child and wished me all possible good, just as for his own child.[12]

Rymar claimed that his parish priest had had a crucial influence on his intellectual development and life choices. Born in 1851, Hryhorii Rymar began his education in the village and entered the third grade of the normal school in Drohobych when he was 18 years old. Rymar was the best student in his class and was only in second place on the official list due to the fact that corrupted social relationships required the top spot to be reserved for the son of the local financial commissar.[13]

Rymar not only began normal school much later than other students, but he had to leave it after two years when he was drafted into the army in 1871. After a three-year stint in Vienna, with fire-workers in the artillery, he became a sergeant. In 1874 he joined the fifth command of the gendarmerie in L'viv and served for five years in Ternopil', Lopatyn and Brody (close to the Russian border). At first he served as a private, but after a six-month sergeants' course he advanced to the rank of Postenführer, and became commander of the outpost in his native village of Dobrivliany.[14] Because of illness he had to leave the service, and with a yearly pension of 150 Gulden, he settled down in Dobrivliany in 1879. In 1880 he was appointed the community's scribe, and he held this position until May 3, 1886, on which date he was arrested.[15] In his autobiography Mykhailo Zubryts'kyi writes that Rymar:

knew all our legal decrees better than many graduates of the law school.[16]

Two other priests, besides Antonii Chapel's'kyi, also figure prominently in Rymar's biography. Both of them were his classmates in Drohobych: Mykhailo Zubryts'kyi and Ivan Chapel's'kyi, his pastor's 
son. There was also the influence of Ol'ha Bilyns'ka, a local teacher and one of the first graduates of the first Galician teachers' seminary for women, and of the pastor's daughter, Natalia Chapel's'ka. Both clerical and female influences are downplayed and overshadowed in the representation centering on Ivan Franko.

Similar things can be shown for other members of the affair. Many people were involved, and peasants exchanged, even if asymmetrically, ideas, texts and contacts with these other people. For example, Hryhorii Rymar could have gotten in touch with Ivan Mykhas not through Ivan Franko but through their respective parish priests, who apparently were related and sometimes paid visits to each other.

Another important aspect of the story is the intra-community dynamic and network. Defendants from Dobrivliany shared a similar social background and, together with the other peasant activists mentioned here, formed a fairly cohesive social group distinct from other co-villagers. Peasants involved in the affair in no way were the poorer members of the community as is usually claimed by the works on rural socialists and radicals in Galicia. In fact, labeling many of them just "peasants" eclipses other important aspects of their social status. Hryhorii Rymar's biography and his situation as a retired gendarme with a stable pension is a good example. Moreover, Rymar held the influential position of community scribe, while both Ivan Stupak and Hryhorii Berehuliak were either part of the village government or had close ties with its members. In fact, all three constituted the leadership of the reformist party in the village and struggled against the previous village establishment, whom they accused of corruption, negligence, conservatism and superstition.

As the leader of a reformist village party, Hryhorii Rymar was obviously not an organic part of the village community, and in his texts there is a sense of his alienation from the community. Although he claimed to be a peasant on the pages of the popular press, he was not perceived as a peasant by his co-villagers. This was also the case with Ivan Mykhas. In terms of the intensity of their intellectual exchange, it seems that both Rymar and Mykhas were more strongly attached to intellectuals like Ivan Franko than to their co-villagers or even to their village supporters. While the older village establishment they were fighting was well-connected with the local administration, the reformist peasants sought support from the opposition: democratically thinking intellectuals of both nationalities and those in the Ukrainian national movement, which was in opposition 
to the province's authority and was searching for ways to involve and reeducate peasants.

\title{
P A R T II
}

Whatever differences and social distinctions existed within the villages, the social distance between those involved to the affair and their intellectual mentors was huge. There is no doubt that for the intellectuals, people like Rymar were first of all peasants. And this despite the fact that many of these intellectuals, like Ivan Franko himself, were peasant sons. The crucial distinction in this case seems to be a gymnasium education, usually followed by a university one. In his writings Franko often has a character, an enlightened and educated man, who returns to the village, settles there and works among local peasants, enjoying a simple life close to nature as well as his own usefulness to peasants and the work he does with them. However, Franko's own experience between 1881 and 1883 when he lived in the village was far removed from this idyllic picture.

In one of his letters from Nahuievychi he wrote the following:

\begin{abstract}
Man, my life here is quite ugly, work all the time, [work] that kills my thoughts and tires me so much that I cannot get together for some spiritual work. I feel, as my "literary energy" disappears, how much more difficult it gets every time to write anything, in how many fewer things I succeed. There are many things I have started and even more I have thought of but have neither time nor powers to finish. I lack here some lively company, lack everything that wakes thoughts in a man and gives some sensation, [this is a] monotonous and truly animal life.[17]
\end{abstract}

What farming work Franko did was only because his stepfather insisted on it. His contact with peasants was limited as well. Despite this, he advised his educated friends of peasant origin to return to their villages and start farming.[18] Serhii Podolyns'kyi, a Ukrainian socialist émigré from the Russian Empire living in Switzerland also argued in favor of settling among peasants, which would be more effective than the Russian narodnik's practice of "two or three months travels along the Volga or temporary work in a factory."[19] In practice, however, it appears that the only way to appeal to peasants was through people from the communities, half-educated but still on their side of the great divide between plebeian and high. Even priests of peasant origin who went back to the villages felt themselves totally alienated from the communities in which they had to live and work. That is why peasant activists like those 
involved in the Dobrivliany affair were so important for the intellectuals who in the 1880 s tried to approach the peasantry.

There is also no doubt that these intellectuals saw the exchange that took place between them and the peasant activists as an unequal one they thought rather in terms of having certain ideas transmitted to the peasants and making sure that the peasants understood them. But what were the intellectuals trying to transmit to the people? If we look at accusations made at the Dobrivliany trial, the answer is socialism and anti-religious agitation. Socialism was about the transformation of existing social relationships through the transformation of the relationships of production, which at the trial figured as the idea of a violent overthrow of the existing social order. The prosecutor did not find much evidence of this idea and so concentrated on anti-clerical agitation: all kinds of the peasants' blasphemous acts and jokes would qualify for this.

Both socialism and anti-clericalism can be found in the propaganda of the leftist Ukrainian intellectuals. In the late 1870s several popular socialist pamphlets were published and smuggled into Galicia. Largely they were read by Ukrainian students, but they also reached the group of peasant activists formed around Dobrivliany. In Galicia Ivan Franko himself tried to write a popular interpretation of Das Kapital, and he also included the labor theory of value in a pamphlet on his ideal educated man coming back to the village.

Another project which Franko developed under the influence of Drahomanov, another Ukrainian socialist émigré from the Russian Empire, was "anti-clericalism." The project was based on exploiting tensions existing between the priests and their peasants, and transforming them into an ideologically motivated anti-clericalism. This would have undermined the power of individual priests as well as the power of the Church. In connection with this project Franko popularized rationalist critiques of the Bible, hoping to feed peasant skepticism tow ards the Holy Scripture and religion in general.[20] This project was conceived as a project of modernization, changing the last of the relationships tying peasants with the old order. Franko says explicitly that his anticlericalism is not about any alleged exploitation of peasants by priests:

The real cause [of tensions between priests and peasants], in my opinion, lies deeper. Having slowly felt constitutional freedom our people shook off the landlords [in the original by mistake priests: "popiv" instead of "paniv"], 
mandators, stewards, old bezirks; they have little business with the district captaincy; and only with the priest do they continue to stay in the same relation.[21]

In 1883 Franko recalled that when in 1880 young Polish and Ukrainian socialists were discussing questions related to the cooperation and common work:

One of the more important subjects of the discussion was the question: should we spread pure socialism among the people, or socialism together with rationalism and positivism? Ukrainian Socialists supported the second, broader program, encountering resistance from Polish socialists, or rather a lack of understanding of the need for such broader work.[22]

We can claim that this "broader work" became the basis for the radical intellectuals' participation in the national movement. The national movement, which was gaining intellectual respectability and popular support to challenge the Polish landlords' domination of the province, also tried to intervene into peasant society; peasant culture had to be remolded according to the national standard. Since the late 1860s there had been regular series of popular publications, popular newspapers and actions targeting peasants. In the 1880s, under the influence of positivism, the movement's younger activists started looking for new, more scientific ways of intervention. For many of them socialism was one such way. This positivist belief in social science became common ground for them and leftist Ukrainian intellectuals.

\section{P A R T I I I}

Let's turn now to the peasant response to these projects, how they read them, and how they wrote about them. In the early 1880s all those involved in the trial were in a struggle against corruption and fraud in the village government, and were for the introduction of abstinence. They founded reading clubs, tried to propagate an ethic of hard work and thriftiness, and fought against superstitions and "bad customs" like celebrating weddings and baptisms with long bouts of drinking. Immediately after the trial those involved fell silent and their names disappeared from the pages of the Ukrainian newspapers, but in the 1890s they resumed their activities. Rymar himself published several articles in Khliborob, a popular newspaper of the newly founded Radical Party, in 1893 just before his death.

It is very characteristic that the first article Rymar contributed to the newspaper bore the title "How much does a wedding cost for the poor 
farmer?" In this article he picked up one of his favorite themes from the early 1880s, as if not much had changed since that time. Rymar's obsession with thriftiness is also visible in an article on village schools, which is also from 1893.[23]

Probably the most interesting article of Rymar's is titled "Oh, these Radicals!" [24] At the beginning of this article, he assumes the posture of a simple peasant, mentioning that he does not know much and claiming to stay at home all the time. However, some rumors about radicals have still managed to reach him. He has heard these rumors and thought that the radicals were godless, evil and dangerous people. Here we find an interesting pattern: the peasants who were involved in radical activities in the 1880s would claim in the 1890s that they were converting them just now and this was their first exposure to radicalism.[25] One can recognize this as a rhetorical strategy; however, the fact that this was not a single case, and that the editors, to whom the peasants sent these letters, had known them very well back in the 1880 s, seems to indicate that the peasants did not perceive their activities in the 1880s as "radical" and directly connected with the foundation of the Ruthenian-Ukrainian Radical Party in 1890. The party was for them a new phenomenon. Parodying the way the thinking of "simple peasants" appeared in popular pamphlets and newspapers, Rymar presented how he figured out what the Radical party was about as follows:

I thought like this. There are more people on earth who can reason, not only crazy radicals; so if the Radicals wanted to do something evil, then other smart people would never allow for it, they would put them in straitjackets and cure them so that they could come back to their full powers of reasoning. The land, the state has an army, has wise people.

And if they were really so godless that they do not believe in God, then Lord God has power over them: if the Lord God handled proud Angels and pushed them down to Hell, while Angels had more importance than people, so Lord God could also handle these radicals, who are not Angels but simple people...

So I think if God really disliked radicals as many people do, he would put them in their place because he is the Almighty Father above all humans, Radicals included! One strong earthquake - and the bodies of radicals would be underground and their souls in Hell.

No natural disaster occurred, however, and this allowed Rymar to surmise that people attacking radicals were pursuing their own hidden interests, interests that had nothing to do with God's attitude. After 
hearing all the rumors, Rymar wished to have a look at the radical Khliborob. A nearby farmer had a copy of the newspaper, so he borrowed it:

I took that Khliborob to my house and read and read it, and was afraid not to get infected with something bad from it because I had already heard that hundreds of swear words had been hurled at this newspaper. But then I became braver and read without fear, thinking that if Mr. Prosecutor had not been afraid to read it while censoring it, why should I, a simple peasant, be afraid of reading it!!

Now Rymar switches to a more serious mode. While reading the radical newspaper, Rymar allegedly discovered that radicals were writing extremely wisely: "only the truth, the pure truth" as, for example, when arguing for the introduction of general elections. They want all the people, no matter what their estate and tax class is, to elect representatives of their own.

This wish of theirs is absolutely just. Land, wealth and taxes do not need councilors or deputies, people only require them to organize land, earthly wealth and taxes in relation to people and their social and state needs. Land in general is God's and the only real councilor above it is Lord God. Lord God created land, mountains, clothes, water, dryness, warmth and rules over it. Land will not attack or abuse each other because its every part lies in its place and does not move. Land will not die of hunger, it does not need accommodation, clothing, or fuel. In this respect it does not need a counselor at all and it does not need to vote.

People, living beings require deputies or people's representatives and therefore the vote, so that these deputies will see to it that there is order among them, that they can live in security and have everything else necessary in society for human life and order.

A man comes into this world according to God's will, which is general and equal for all people, and through this very coming into the world he acquires the right to life in this world; only because of this must a man also acquire this general human right on earth: to take part in the establishment of customs and orders that regulate through human laws the mode and the order of human life and security in society and in the state. Every man who came into the world by God's will must be able to satisfy his most general needs, must be able to support his own life from the same land on which he was born, because to another land, as for example Mars, Venus or Mercury, etc., no railway has yet been constructed, so one cannot go there from this land to earn the bread necessary for life.

This article is very important for us because it provides clues to what the blasphemy and agitation against the social order that Rymar was accused in 1886 could look like. It can be said for sure that Rymar was not an 
atheist and his anticlericalism was not directed against all priests. In other letters, letters from the community and by a local priest, it is evident that Rymar was concerned with the priest's claims to power and attempts to reinstate paternalist patronage over the village community, controlling its political and social life. Rymar's alternative was the secular selforganization of the community around an elected self-government and a civilized public forum in the shape of a village reading club.

Rymar's reflections also show that his ideas about humankind draw on early Ukrainian socialist pamphlets. He reworked them "creatively," leaving out the parts about the origin of value in labor and revolutionary struggle, and reading them rather in the tradition of popular publications for peasants from the 1860s and 1870s, which emphasized moral reform, thriftiness and enterprise. For example, the pamphlet "On Farming" states "all wealth comes from work," meaning that labor power is the source of all value produced.[26] At the same time, Rymar interprets this as a statement that diligent work is necessary for prosperity. The pamphlet says that all the evil in human relationships comes from the wish to force others to work for oneself, from which state and class divisions derive. Rymar interprets this as personal envy and evil tendencies, which can be tamed or held in check by a legal framework.[27] He states explicitly that he is not sure about the source of all evil but is inclined to see it in the nature of some individuals while he describes good in terms of individual freedom and the inalienability of property.

In the texts left by the peasants involved in the Dobrivliany affair, one would never find anything about "underpaid labor," and this was powerfully stressed in the socialist pamphlets they apparently read. The pamphlets stated that one could not look for some just price, that under current relationships of production one was never paid the value he actually produced with his labor.[28] According to the socialist pamphlets, capital could not be acquired by means other than exploitation and the appropriation of the others' labor.[29] And the peasant activists in Dobrivliany and Volia Iakubova argued for the individual's and community's prosperity, entrepreneurship and thriftiness.

Rymar misses all the discussion in Podolyns'kyi's texts of the oppressive legal system, of how Roman law was pressing out the remains of the communal order and the common usage of natural resources. This does not come as a surprise if we remember his gendarme background and his respect for proper legal procedures. The activists from Dobrivlainy 
and Volia Iakubova tried to get into power so that they could control the village government and make this part of the state structure operate justly. In his reflections on the natural rights and inherent good in humans, Rymar eagerly picks up on descriptions of joyful communal life in the future.[30] This communal life is supposed to save everyone from envy and enmity, and it is something Rymar would like to implement in his community but with the help of law and order, through discipline not the overturning of social relationships.

\section{P A R T IV}

The Dobrivliany trial did not have as wide a resonance as other trials against socialists. Despite the fact that they read socialist pamphlets, these peasants were no socialists, something clear to everyone. Nevertheless the case was used to launch attacks against peasant reading clubs, the Ukrainian movement, socialists, and even secular teachers. The conservative Czas, which was published in Krakow, presented this case as proof of the fact that reading clubs too often became "pivots of unhealthy agitation." It also seems that Czas feared the uncontrollable action of peasant masses misinterpreting socialism more than socialism itself.

Czas also used the case to attack the Ukrainian national movement in general. In this attack, the Ukrainian movement was associated with nihilist and socialist trends. A similar position was taken by the Russophile newspaper Novyi Prolom, in which the Ukrainian movement and its printed production were blamed for the "demoralization" of the peasantry and the spread of socialist and anti-clerical agitation.

The Ukrainian answer to these attacks was formalized by Dilo, leading Ukrainian daily newspaper published in L'viv.[31] First, Dilo assures its readers:

that most of the Ruthenian reading clubs rest on a legal and moral-religious foundation. The Ruthenian intelligentsia as well as our peasants and artisans are religious, moral, and respect the law.

The following passage is especially telling of Dilo's project:

this case contains much drastic material that does not lend itself to discussion in our paper because the paper's editorial board sticks as closely as possible to the principle of forging agreement and harmony among all the estates in our [Ruthenian] society. This is the only guarantee of our power. 
Dilo took a hard stance against the agitators sowing unrest while staying safely outside of the villages. However, Dilo blamed not only the socialist agitators but also those members of the intelligentsia who looked upon enlightening the peasants unfavorably. The following passage refers to parish priests:

They sin when they remain even-hearted and indifferent to the noble attempts of bringing people to enlightenment. And they commit an even greater, let us say inexcusable, sin when they accept the ignoble role of the extinguishers of the spirit and light.

Dilo blamed the pastor of Volia Iakubova for siding with the unenlightened and becoming the enemy of the reading club. As a counterexample, it names a certain Rev. Charnets'kyi, who founded a dozen reading clubs himself. According to the newspaper, the duty of village pastor is to prevent dangerous symptoms instead of complaining to the authorities. It also blamed the Przemyśl Consistory for handing the case over too easily to state authorities and not paying attention to the fact that aside from the scribe, two cantors were accused by the priest. The article concludes "Let the Sambir trial be the first and the last of this kind among us." [32]

\section{CONCLUSIONS}

Despite the fact that the influence of the intellectuals and the city on the peasants from Dobrivliany has usually been represented in historiography as socialist, we must note that the periodicals to which these peasants contributed were not socialist but national(ist), and that in a letter from Nahuievychi, dated 1882, Ivan Franko (the most important among the "socialist" spiritual fathers of the peasants from Dobrivliany and Volia Iakubova) also located himself in the camp of nationalpopulists, albeit on its left wing and always emphasized that he was a socialist of a certain kind.[33] Socialism in this case cannot be understood outside of the particular context of the national project.

There was very little socialism in the peasants' ideas, but neither was there much nationalism in the programs in peasant texts. There was very little national antagonism: the worst enemies of the Ruthenian peasant activists in this case are other Ruthenians, peasants as well priests. There are no references to Polish landlords and robot times, but there are strong connections with past and present Ruthenian projects. It is important to realize that at this point neither nationalists nor socialists had any 
organizational means to reach down to the peasant masses. That explains why for both of them connecting with concrete people in the villages was of primary importance.

On the other hand, if nationalism and socialism are understood as "projects" at work, projects to which peasants were exposed and which targeted peasants, then these village conflicts were indeed consequences of them. These new projects were not simply about indoctrinating peasants, they also worked to empower them, making them believe in their own importance. They transformed peasant distrust of the world of gentlemen and local power conflicts into integral parts of a larger process occurring objectively and simultaneously in many communities, and in the world in general. Typologically, the intra-community conflicts described in this case belonged to the conflict between "liberal" and "conservative" village elites. Conflicts of this type swept across Spain, France and Italy in the second half of the nineteenth century.[34]

However, in the Dobrivliany case the immediate context of reference for such a conflict was provided not by the nation-state but by the Ukrainian national movement. The peasant activists from Dobrivliany and Volia Iakubova were among the first peasant correspondents to the national newspapers. They were among those exemplary peasants whose words were selected by the movement as representative of the peasantry, and who, in turn, gave their trust to the movement and sought allies there. Unlike in France and Italy, the sources of enlightenment these activists tried to bring to their villages lay outside the state institutions. The entire discussion of this affair took place in the context of the national press, which evaluated and assigned it a place in the narrative of nation-making. It also seems that by narrating the case, evaluating and drawing conclusions from it, this national project tried to incorporate a social (socialist) component. Despite the fact that no declaration demanding an independent Ukrainian nation-state had yet been made, the Ukrainian national project intervened in local conflicts and tried to exercise, to use Ranajit Guha's term, its anticipated hegemony: the hegemony which would become full-fledged in the projected nation-state.[35]

The peasant activists' agenda was reformist: to change the community's balance of power, its mode of politics, morals, and individual habits. Enlightenment was not only about subjective identification with nationality or class, it was about the transformation of subjectivity; their ideal individual was a new individual. Both projects, nationalist and 
radical, appear to have been conspicuously implicated in this agenda. Perhaps these projects had some common and more general connection. This larger connection is seen in the intellectuals' concern with rationalism, positivism, enlightenment and being "European." The Ukrainian national project was invested in this agenda and tried to represent itself as the only viable road to modernity. It did that on the level of representations usurping the right to bring the narrative about local affairs to a larger audience but also on the institutional level organizing a web of reading clubs united in a single nation-wide organization and constituting a national public sphere through which ideas could be disseminated to the targeted audience. Once built and in motion this institutionalized national public sphere replaced networkbased activities, a glimpse of which we have seen in the case of the Dobrivliany affair.

\section{E N D N OTES}

[1] [Hryhorii Rymar], "Liubov do blyzhnioho. Pam'iatka po bl. p. Hryhoriiu Rymari," Khliborob, 1893, No.19.

[2] For the first and fullest description of this case in the scholarly literature see John-Paul Himka, Polish and Ukrainian Socialism: Austria, 1867-1890 (manuscript of Ph.D dissertation: University of Michigan, Ann Arbor, 1976), 409-20; for the same heroes in the context of the Ukrainian national movement see his Galician Villagers, 137-40, 186, 292-3.

[3] This is the approach of all the early accounts of the "Ukrainian Revival" in Galicia. See, for example, Volodymyr Hnatiuk, Natsional'ne vidrodzhennia avstrouhors'kykh ukraïntsiv, 1772-1880 rr.; Mykhailo Vozniak, Iak probudylosia ukraïns'ke zhyttia v Halychyni za Avstrï; but also of some recently published books. See Mykhailo Kuhutiak, Halychyna: storinky istoriï. Narys suspil'no-politychnoho rukhu (XIXst.-1939r.) (Ivano-Frankivs'k, 1993).

[4] Ivan Lysiak-Rudnyts'kyi, in distinguishing clearly between the "modern nation" and pre-modern "people" also stated that "for the Ukrainians, struggle for national and social liberation was one." - See his "Ukraïntsi v Halychyni pid avstriis'kym panuvanniam," in Ivan Lysiak-Rudnyts'kyi, Istorychni ese (Kyïv: Osnovy, 1994), 424. This explanation was finalized in John-Paul Himka's Galician Villagers and remains common in historical work on Habsburg Galicia. For an example, see Kai Struve, "Social Emancipation and National Identity. Polish and Ruthenian Peasants in Galicia Compared," paper given on the Congress of International Association of Ukrainian Studies, Chernivtsi, 26-29 August 2002.

[5] John-Paul Himka, "The Construction of Nationality in Galician Rus': Icarian Flights in Almost All Directions," in Ronald Grigor Suny and Michael D. Kennedy (eds.), Intellectuals and the Articulation of the Nation (Ann Arbor: University of Michigan Press, 1999), 109-64. 
[6] I borrow this term from Arjun Appadurai, Modernity at Large: Cultural Dimensions of Globalization (Minneapolis, London: University of Minnesota Press, 1996), 5, despite the fact that he applies it to the particular conditions of contemporary globalized world.

[7] Rogers Brubaker and Frederick Cooper, "Beyond 'identity,'" Theory and Society 29 (2000): 20-1.

[8] Mustafa Emirbayer and Jeff Goodwin, "Network Analysis, Culture, and the Problem of Agency," The American Journal of Sociology 99.6 (1994): 1411-54.

[9] Andriy Zayarnyuk, Framing the Ukrainian Peasantry in Habsburg Galicia, 18461914 (With a Focus on the Sambir Area), (Ph.D thesis, University of Alberta, 2003).

[10] It is interesting that Rymar received this book from a priest, most probably Rev. Ivan Chapel's'kyi, son of Rev. Antin Chapel's'kyi. See Franko's letter to Drahomanov Lystuvannia I. Franka i M. Drahomanova, 195.

[11] The distinction Berehuliak makes here between himself, woodcarvers and "peasants" is very interesting.

[12] [Hryhorii Rymar], "Liubov do blyzhnioho. Pam'iatka po bl. P. Hryhoriiu Rymari," Khliborob, 1893, No.20.

[13] Manuscript Division of L'viv Scientific Library (further on- VR LNB), fond (further on - f.) Vasyl' Shchurat, sprava (further on - spr.) 922, papka (further on - p.) 27 , a.8.

[14] VR LNB, f.Ivan Levyts'kyi, opys (further on - op.)2, spr.2702, p.80.

[15] Ibid.

[16] VR LNB, f.Vasyl' Shchurat, spr.922, p.27, a.8.

[17] Franko to Belei (summer 1882) in Ivan Franko, Zibrannia tvoriv u p'iatdesiaty tomakh, t.48 (Kyïv: Naukova dumka, 1986), 316-17.

[18] This was his advice to Ivan Maksymiak, Lystuvannia I. Franka i M. Drahomanova. Materiialy dlia kul'turnoi i hromads'koi istorii Zakhidnioi Ukrainy, t.1 (Kyïv: komisiia Zakhidnioi Ukrainy Vseukrains'koi Akademii Nauk) (Kyïv, 1928), 43.

[19] Serhii Podolyns'kyi, "Lysty do V. Smirnova," in Serhii Podolyns'kyi, Roman Serbyn (ed.) Vybrani tvory (Ukrains'ke istorychne tovarystvo, 1990), 63.

[20] Lystuvannia I. Franka i M. Drahomanova, 99.

[21] Hromads'kyi Druh, 1878, 260.

[22] Ivan Franko, "Popy i ekonomichne polozhennia ukrains'koho narodu v Halychyni," in Ivan Franko, Zibrannia tvoriv u p'iatdesiaty tomakh, t.44, kn.1 (Kyïv: Naukova dumka, 1986), 155-56, ft.1.

[23] Hryhorii Rymar, "Interesy hromady u teperishnia mistseva shkil'na rada," Khliborob, 1893, No.8 and 9.

[24] Hryhorii Rymar, "Oi ti radykaly, radykaly!", Khliborob, 1893, No.6.

[25] This was also the case with Ivan Mykhas, who claimed to have converted to radicalism under his friend's influence and Jesus Christ's teachings only in 1892.

[26] [Mykhailo Drahomanov] Lyps'kyi, Pro khliborobstvo. Rozmova tretia. Iak de zemlia podilena i iak by treba iii derzhaty, (1877), V.

[27] Ibid., VI.

[28] Serhii Podolyns'kyi, "Pro bahatstvo i bidnist'," in Roman Serbyn (ed.) Vybrani tvory (Ukraïns'ke istorychne tovarystvo, 1990), 37.

[29] Serhii Podolyns'kyi, "Pro bahatstvo i bidnist'," 41. 
[30] Ibid., 132.

[31] “Protses selian z Drohobytskoho," Dilo, 1886, No.62, 7(19).06.1886.

[32] Ibid.

[33] Franko to Partyts'kyi in Ivan Franko, Zibrannia tvoriv u p'iatdesiaty tomakh, t.48 (Kyïv: Naukova dumka, 1986), 335.

[34] For the Italian example, see Roland Sarti, Long Live The Strong: A History of the Rural Society in the Apennine Mountains (Amherst: University of Massachusetts Press, 1985). For the French example, see conflicts between village pastors, mayors and schoolmasters in Barett Singer, Village Notables in Nineteenth-Century France: Priests, Mayors, Schoolmasters (SUNY series on European social history) (Albany: State University of New York Press, 1983). It seems that nothing similar happened in Russia. While tensions between priests and village communities no doubt existed, they were never translated into something bigger, never went through the prism of ideology, never got into the space of public debate.

[35] Ranajit Guha, Dominance without Hegemony: History and Power in Colonial India (Cambridge, MA: Harvard University Press, 1997), 101. 